\title{
Vinyl Polymerization. CCCC. Radical Polymerization of Methyl Methacrylate Initiated with Micrococcus lysodeiplicus
}

\author{
Minoru IMOTO ${ }^{\dagger}{ }^{\top}$ Tatsuro OUCHI, Masaya INABA, \\ Tai TOKUYAma ${ }^{\dagger \dagger}$ Hitoshi OBATA, Naoki FuKUDA, \\ and Tsutomu IWAMOTO ${ }^{\dagger \dagger}$ \\ ${ }^{\dagger}$ Laboratory of Synthetic High Polymers, Faculty of Engineering, Kansai University, \\ 3-3-35 Yamate-cho, Suita, Osaka 564, Japan. \\ ${ }^{\dagger \dagger}$ Laboratory of Applied Biochemistry, Faculty of Engineering, Kansai University, \\ 3-3-35 Yamate-cho, Suita, Osaka 564, Japan. \\ ${ }^{+{ }^{\dagger}}$ Laboratory of Electron Microscopy, Medical School, Osaka City University, \\ 1-5-7 Asahi-machi, Abeno-ku, Osaka 564, Japan.
}

(Received April 19, 1980)

\begin{abstract}
The polymerization of methyl methacrylate with Micrococcus lysodeiplicus was carried out in water, and the reaction was found to proceed through a radical mechanism. The effects of the quantity of reagent on the rate of polymerization and selectivity of vinyl monomer were studied. The change in the sectional view of the polymerization system was observed with a transmission electron microscope.
\end{abstract}

KEY WORDS Micrococcus lysodeiplicus / Radical Polymerization / Methyl

Methacrylate / Transmission Electron Microscope /

Recently, it was reported ${ }^{1,2}$ that the cells of yeast, Saccharomyces cerevisiae, could initiate the polymerization of methyl methacrylate (MMA) in the presence of $\mathrm{Cu}(\mathrm{II})$ ion. Polymerization was found to proceed in the exterior and interior of the cell, particularly in the cell wall. The present paper deals with polymerization by the cells of bacteria, Micrococcus lysodeiplicus (abbreviated as Mc 1). The possibility of radical polymerization, the effects of the quantity of reactant on the conversion of MMA and the selectivity of the vinyl monomer are studied. Moreover, the traits of the cells before and after polymerization, were observed with a transmission electron microscope.

\section{EXPERIMENTAL}

\section{Materials}

Micrococcus lysodeiplicus I.F.O. 3333 was provided by the Research Institute of Fermentation (Osaka). Cells were grown at $\mathrm{pH} 7.3$ in an aqueous media containing $10 \mathrm{~g}$ of Beef Extract, $10 \mathrm{~g}$ of polypepton, and $5 \mathrm{~g}$ of $\mathrm{NaCl}$ in $1 \mathrm{dm}^{3}$. The culture was incubated at $30^{\circ} \mathrm{C}$ for $3 \mathrm{~d}$ with shaking. The cultured broth was centrifuged at $6000 \mathrm{rpm}$ for $30 \mathrm{~min}$ and the supernatant was excluded. The cells, constituting the precipitate, were washed twice with cold distilled water to remove residual metal ions and other soluble constituent.

MMA and other monomers were purified by the usual methods. Copper(II) chloride (special grade) was used without further purification. The water was ion-exchanged and distilled.

\section{Procedures}

MMA, water, and other reagents were placed in a tube which was then sealed in a vacuum after thawing with nitrogen and incubated at 30 or $85^{\circ} \mathrm{C}$ and shaken or allowed to stand. After a certain time, the contents of the tube were poured into a large amount of methanol in order to precipitate the polymer formed. After filtration, the product was thoroughly washed with methanol, dried in a vacuum, and then weighed. The conversion of MMA was calculated by the following equation. 
М. Імото et al.

Table I. Polymerization of vinyl monomers ${ }^{\mathbf{a}}$

\begin{tabular}{|c|c|c|c|c|c|c|c|c|}
\hline \multirow{2}{*}{$\frac{\text { Mc } 1}{\mathrm{~g}}$} & \multirow{2}{*}{$\frac{\mathrm{CuCl}_{2} \cdot 2 \mathrm{H}_{2} \mathrm{O}}{\mathrm{g}}$} & \multicolumn{7}{|c|}{ Conversion $/ \%$} \\
\hline & & MMA & EMA & $i$-PMA & $n$-BMA & $t$-BMA & $\mathrm{AN}$ & $\mathrm{St}$ \\
\hline 0 & 0 & 0 & 2.0 & 1.9 & 1.0 & 1.0 & 0 & 1.5 \\
\hline 0 & $5 \times 10^{-3}$ & 0 & 0 & 0 & 0 & 0 & 0 & 1.8 \\
\hline 0.05 & 0 & 0.2 & 0.2 & 0.6 & 1.0 & 3.5 & 0 & 2.1 \\
\hline 0.05 & $5 \times 10^{-3}$ & 10.8 & 1.0 & 0.1 & 0.2 & 0.2 & 1.2 & 2.0 \\
\hline
\end{tabular}

a Monomer, $3 \mathrm{~cm}^{3} ; \mathrm{H}_{2} \mathrm{O}, 10 \mathrm{~cm}^{3} ; 30^{\circ} \mathrm{C} ; 10 \mathrm{~d}$; with shaking.

EMA, ethyl methacrylate; $i$-PMA: isopropyl methacrylate; BMA, butyl methacrylate.

$$
\text { Conversion }(\%)=\frac{\text { Weight of products }(\mathrm{g})-\text { Initial weight of cells }(\mathrm{g})}{\text { Weight of MMA in the feed }(\mathrm{g})} \times 100
$$

It was confirmed by turbidimetry that no multiplication of the cells took place during the course of polymerization at $30^{\circ} \mathrm{C}$ for $10 \mathrm{~d}$. The cells, before and after polymerization, were observed with a transmission electron microscope. ${ }^{1}$ The numberaverage degree of polymerization $\left(\bar{P}_{n}\right)$ of poly(MMA) produced was estimated from the viscosity determined in benzene at $30^{\circ} \mathrm{C}$, using Welch's equation. ${ }^{3}$

\section{RESULTS AND DISCUSSION}

\section{Selectivity of Vinyl Monomers}

Polymerization of various monomers was carried out in a system of $\mathrm{Mc} 1, \mathrm{Cu}(\mathrm{II})$ ion, and water. The results are given in Table I.

The conversion of styrene (St), acrylonitrile (AN), and methacrylates other than MMA were in the range of thermal polymerization or experimental error. Only MMA was found to be polymerized.

\section{Confirmation of Radical Mechanism}

In order to confirm that polymerization proceeded through a radical mechanism, the copolymerization of $\operatorname{MMA}\left(\mathbf{M}_{1}\right)$ with $\operatorname{St}\left(\mathbf{M}_{2}\right)$ was carried out with shaking and the results are shown in Figure 1. From the curve, $r_{1}$ and $r_{2}$ were calculated to be 0.48 and 0.54 , respectively. Thus, it is concluded that the polymerization proceeded through a radical mechanism.

Moreover, the radical mechanism was verified by the addition of hydroquinone as a radical scavenger. The results are shown in Table II. On addition of

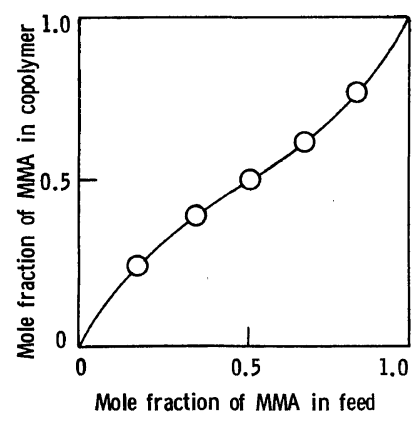

Figure 1. Composition curve of copolymerization of MMA $\left(M_{1}\right)$ with St $\left(M_{2}\right):(M M A+S t), 3 \mathrm{~cm}^{3} ; \mathrm{H}_{2} \mathrm{O}$, $10 \mathrm{~cm}^{3} ; \mathrm{Mc} 1,0.05 \mathrm{~g} ; \mathrm{CuCl}_{2} \cdot 2 \mathrm{H}_{2} \mathrm{O}, 5 \times 10^{-3} \mathrm{~g} ; 30^{\circ} \mathrm{C} ; 6 \mathrm{~d}$; with shaking.

Table II. Inhibition of the polymerization of MMA with hydroquinone ${ }^{\mathrm{a}}$

\begin{tabular}{|c|c|c|}
\hline \multirow{2}{*}{ Reaction } & Hydroquinone & Conversion \\
\hline & g & $\%$ \\
\hline \multirow[t]{2}{*}{ With shaking } & 0 & 3.3 \\
\hline & 0.1 & 0 \\
\hline \multirow[t]{2}{*}{ On standing } & 0 & 18.1 \\
\hline & 0.1 & 0 \\
\hline
\end{tabular}

${ }^{a}$ MMA, $3 \mathrm{~cm}^{3} ; \mathrm{H}_{2} \mathrm{O}, 10 \mathrm{~cm}^{3} ; \mathrm{Mc} 1,0.05 \mathrm{~g} ; \mathrm{CuCl}_{2} \cdot 2 \mathrm{H}_{2} \mathrm{O}$ $1 \times 10^{-3} \mathrm{~g} ; 30^{\circ} \mathrm{C} ; 10 \mathrm{~d}$.

$0.1 \mathrm{~g}$ of hydroquinone, no formation of poly(MMA) was observed. 
Effect of the Quantity of $\mathrm{Cu}(\mathrm{II})$ Ion on the Polymerization of $M M A$

The effect of the quantity of $\mathrm{Cu}$ (II) ion on the conversion of MMA was brought about on the polymerization at 30 or $85^{\circ} \mathrm{C}$ by shaking (Figures 2 and 3) and then allowing the system to stand (Figure 4). From these figures, the presence of $\mathrm{Cu}$ (II) ion was found to be indispensable to the polymerization.

Furthermore, in the absence of Mc 1, no polymerization was observed. This and the decrease in the conversion of MMA by excess $\mathrm{Cu}$ (II) ion may be explained by he following inhibition reaction of propagating radical with $\mathrm{Cu}(\mathrm{II})$ ion.<smiles>CCC[C+](C)(C(=O)OC)C(Cl)Cl</smiles><smiles>CCCC(C)(Cl)C(=O)OC</smiles>

It should be noted that both conversion curves in Figures 2 and 3 are similar to each other. The timeconversion curve of the polymerization of MMA is shown in Figure 5. The white and black circles indicate the conversions of MMA in the absence and presence, respectively, of Mc 1. Although there was a short induction period, a good linear relationship was obained. The number-average degree of polymerization, $\bar{P}_{n}$, of poly(MMA), which was isolated by the extraction with benzene, was almost the same as that during the polymerization.

Effects of the Quantity of MMA on Polymerization

The quantities of $\mathrm{Mc} 1, \mathrm{Cu}(\mathrm{II})$ ion, and $\mathrm{H}_{2} \mathrm{O}$ were kept constant and the polymerization was carried out at $30^{\circ} \mathrm{C}$ for $10 \mathrm{~d}$ with shaking. The results are shown in Figure 6. The polymer yield in $\mathrm{g}$ increased gradually with the quantity of MMA.

\section{Effect of the Quantity of Mc 1 on the Polymerization of $M M A$}

Varying the quantity of Mc 1 and keeping constant at the quantities of $\mathrm{Cu}$ (II) ion, MMA, and water constant, the polymerization was carried out at $30^{\circ} \mathrm{C}$ for $10 \mathrm{~d}$ with shaking. The results for the

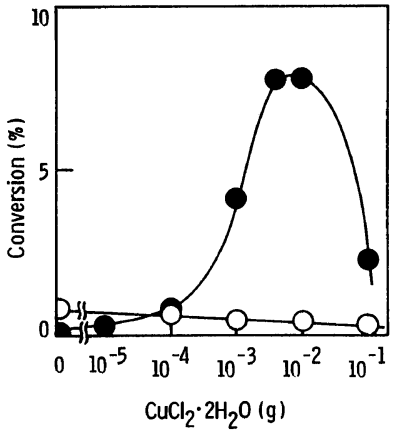

Figure 2. Conversion of MMA vs. quantity of copper (II) chloride: MMA, $3 \mathrm{~cm}^{3} ; \mathrm{H}_{2} \mathrm{O}, 10 \mathrm{~cm}^{3} ; 85^{\circ} \mathrm{C} ; 4 \mathrm{~h}$; with shaking. Mc 1, $0.05 \mathrm{~g}(\mathrm{O})$; Mc 1, $0 \mathrm{~g}\left(\mathrm{O}^{\circ}\right.$.

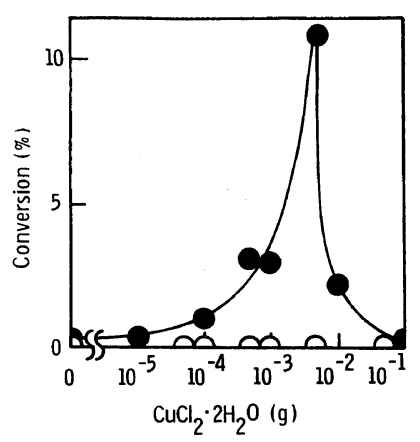

Figure 3. Conversion of MMA vs. quantity of copper (II) chloride: MMA, $3 \mathrm{~cm}^{3} ; \mathrm{H}_{2} \mathrm{O}, 10 \mathrm{~cm}^{3} ; 30^{\circ} \mathrm{C} ; 10 \mathrm{~d}$; with shaking. Mc 1, $0.05 \mathrm{~g}(\bigcirc)$; Mc $1,0 \mathrm{~g}(\mathrm{O})$.

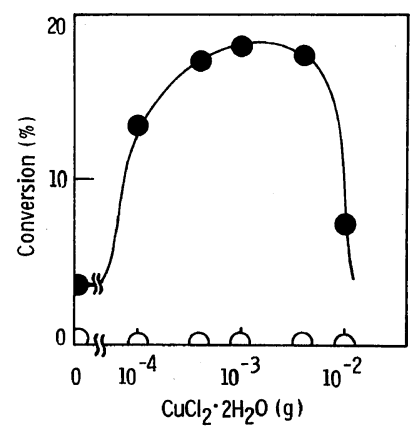

Figure 4. Conversion of MMA vs. quantity of copper (II) chloride: MMA, $3 \mathrm{~cm}^{3} ; \mathrm{H}_{2} \mathrm{O}, 10 \mathrm{~cm}^{3} ; 30^{\circ} \mathrm{C} ; 10 \mathrm{~d}$; on standing. Mc 1, $0.05 \mathrm{~g}(\bigcirc)$; Mc 1, $0 \mathrm{~g}(\bigcirc)$.

conversion of MMA and $\bar{P}_{n}$ of poly(MMA) are shown in Figure 7. The conversion increased with the quantity of Mc 1, reaching a maximum immediately and then decreasing. This was con- 


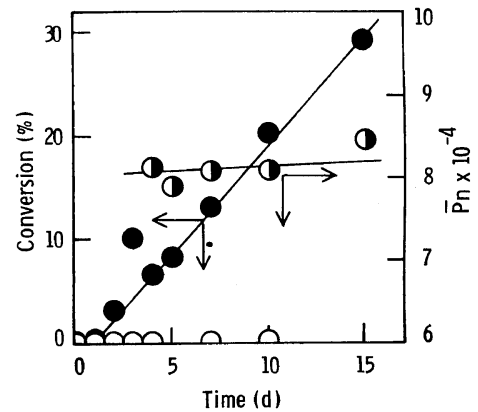

Figure 5. Conversion of MMA and $\bar{P}_{n}$ of poly(MMA) vs. time: $\mathrm{MMA}, 3 \mathrm{~cm}^{3} ; \mathrm{H}_{2} \mathrm{O}, 10 \mathrm{~cm}^{3} ; \mathrm{CuCl}_{2} \cdot 2 \mathrm{H}_{2} \mathrm{O}$, $1 \times 10^{-3} \mathrm{~g} ; 30^{\circ} \mathrm{C}$; on standing. Mc $1,0.05 \mathrm{~g}(\bigcirc)$, Mc $1,0 \mathrm{~g}(\bigcirc)$.

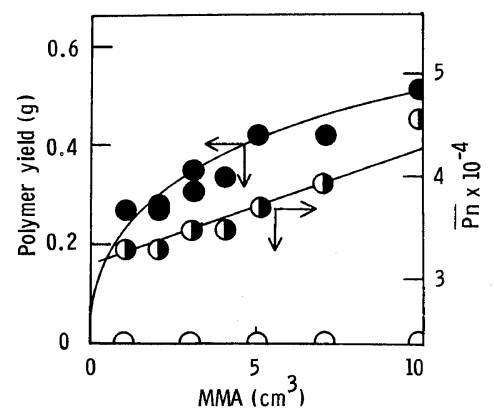

Figure 6. Polymer yield and $\bar{P}_{n}$ of poly(MMA) vs. quantity of MMA: $\mathrm{H}_{2} \mathrm{O}, 10 \mathrm{~cm}^{3} ; \mathrm{CuCl}_{2} \cdot 2 \mathrm{H}_{2} \mathrm{O}$, $5 \times 10^{-3} \mathrm{~g} ; 30^{\circ} \mathrm{C} ; 10 \mathrm{~d}$; with shaking. Mc $1,0.05 \mathrm{~g}(\bigcirc$, (); Mc $1,0 \mathrm{~g}(\bigcirc)$.

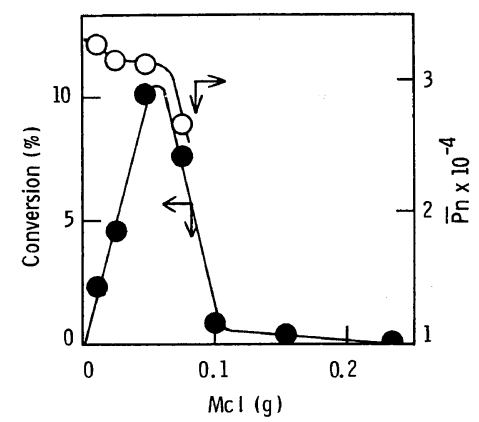

Figure 7. Effect of the quantity of $\mathrm{Mc} 1$ on the polymerization of MMA and $\bar{P}_{n}$ of poly(MMA): MMA, $3 \mathrm{~cm}^{3} ; \mathrm{H}_{2} \mathrm{O}, 10 \mathrm{~cm}^{3} ; \mathrm{CuCl}_{2} \cdot 2 \mathrm{H}_{2} \mathrm{O}, 5 \times 10^{-3} \mathrm{~g} ; 30^{\circ} \mathrm{C} ; 10 \mathrm{~d}$; with shaking.

firmed by repeated experiments. $\bar{P}_{n}$ of poly(MMA) also decreased with the quantity of Mc 1 , beyond a certain quantity of Mc 1 .

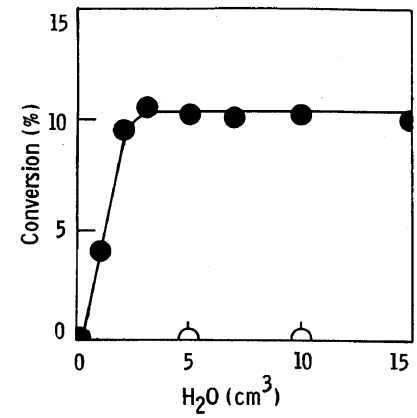

Figure 8. Conversion of MMA vs. quantity of $\mathrm{H}_{2} \mathrm{O}$. MMA, $3 \mathrm{~cm}^{3} ; \mathrm{CuCl}_{2} \cdot 2 \mathrm{H}_{2} \mathrm{O}, 5 \times 10^{-3} \mathrm{~g} ; 30^{\circ} \mathrm{C} ; 10 \mathrm{~d}$; with shaking. Mc 1, $0.05 \mathrm{~g}(\mathrm{O})$; Mc $1,0 \mathrm{~g}(\mathrm{O})$.

Table III. Polymerization of MMA in the presence of large quantity of $\mathrm{Mc} 1^{\text {a }}$

\begin{tabular}{|c|c|c|c|}
\hline Mc 1 & $\mathrm{H}_{2} \mathrm{O}$ & $\mathrm{CuCl}_{2} \cdot 2 \mathrm{H}_{2} \mathrm{O}$ & Conversion \\
\hline g & $\mathrm{cm}^{3}$ & g & $\%$ \\
\hline 0.1 & 20 & $5 \times 10^{-3}$ & 0.2 \\
\hline 0.05 & 10 & $5 \times 10^{-3}$ & 10.8 \\
\hline 0.1 & 10 & $1 \times 10^{-2}$ & 14.3 \\
\hline
\end{tabular}

${ }^{\text {a }} \mathrm{MMA}, 3 \mathrm{~cm}^{3} ; 30^{\circ} \mathrm{C} ; 10 \mathrm{~d}$; with shaking.

This interesting curve with respect to the effect of the quantity of Mc 1 was the same as the curve obtained in the case of yeast cells. ${ }^{1,2}$

In order to confirm that the apparent concentration of Mc 1 in water was not the reason for the rapid decrease in the conversion of MMA, the effect of the quantity of water was studied and the results was shown in Figure 8. It is concluded that under the conditions shown in Figure 8, water was present sufficiently, even if $0.1 \mathrm{~g}$ or more quantity of Mc 1 was' used. Another explanation is given the role of the quantity of $\mathrm{Cu}(\mathrm{II})$ ion. It is considered that, when the quantity of Mc 1 increased, the quantity of $\mathrm{Cu}$ (II) ion became too small to initiate the polymerization. The polymerizations of MMA in the presence of a large quantity of Mc $1(0.1 \mathrm{~g})$ were carried out, as shown in Table III. Thus, it is concluded that Mc 1 required an appropriate quantity of $\mathrm{Cu}$ (II) ion. When $\mathrm{Cu}$ (II) ion was not present sufficiently, Mc 1 acted rather as an inhibitor of the polymerization.

Thus, the only explanation for the above unusual 
behavior is as follows: the contents of some unknown free-radical other than that of the propagating poly(MMA) radicals increased with the quantity of Mc 1 in the feed. This free-radical could be produced by the chain-transfer reactions of the propagating poly(MMA) radicals with the vital macromolecules in the cell, and could scavenge the propagating poly(MMA) radicals. Thus, beyond a certain quantity of Mc 1 , the conversion of MMA and $\bar{P}_{n}$ of poly(MMA) decreases. This is supported by the results of experimental studies on the chaintransfer reaction of poly(MMA) radicals with nucleic acid bases and nucleosides. ${ }^{4}$

\section{Transmission Electron Microscopy}

Figures 9 and 10 present a view of the cells before and after the polymerization of MMA. Comparing Figure 9 with Figure 10, it is clearly seen that the thickness of cell walls differed. Before the polymerization the thickness was averaged at $0.03 \mu \mathrm{m}$, while after the polymerization, it increased to $0.10 \mu \mathrm{m}$. Furthermore, the structure of the protoplasts became spongelike by the polymerization of MMA. These observations suggest that the polymerization of MMA takes place simultaneously in the walls and interior of the cells.

\section{REFERENCES}

1. M. Imoto, T. Ouchi, Y. Nakamura, E. Morita, M. Yamada, Y. Tokuyama, H. Obata, and T. Iwamoto, J. Polym. Sci., Polym. Lett. Ed., 17, 347 (1979).

2. M. Imoto, T. Ouchi, E. Morita, M. Yamada, T.

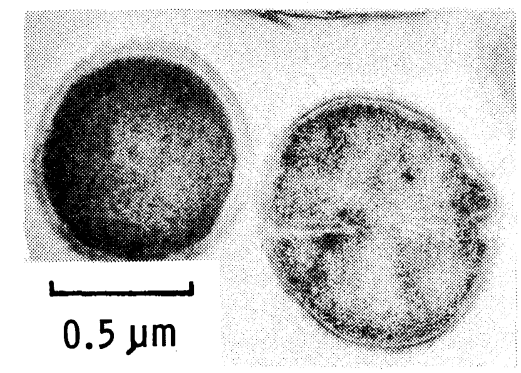

Figure 9. Stained section of Mc 1 cells.



Figure 10. Stained section of MMA-treated Mc 1 cells: Mc 1, $0.05 \mathrm{~g}$; MMA, $3 \mathrm{~cm}^{3} ; \mathrm{H}_{2} \mathrm{O}, 10 \mathrm{~cm}^{3} ; \mathrm{CuCl}_{2} \cdot 2 \mathrm{H}_{2} \mathrm{O}$, $1 \times 10^{-3} \mathrm{~g} ; 30^{\circ} \mathrm{C} ; 3 \mathrm{~d}$; on standing. Conversion of MMA $3.12 \%$. After the polymerization, the product was washed under benzene for $50 \mathrm{~h}$ and acetone for $10 \mathrm{~h}$.

Tokuyama, and H. Obata, Bull. Chem. Soc. Jpn., 53, $256(1980)$.

3. F. J. Welch, J. Polym. Sci., 61, 243 (1962).

4. M. Imoto, A. Kuriyama, and T. Ouchi, Chem. Lett., 1145 (1979). 